\title{
A professional development analysis for Turkish language teachers: What did they expect? What have they found?
}

\author{
Hatice Yurtseven Y1lmaz ${ }^{1}$ and Sedat Sever ${ }^{2}$ \\ ${ }^{1}$ Bursa Uludă̆ University, Faculty of Education, Turkey (ORCID: 0000-0002-9250-5174) \\ ${ }^{2}$ Ankara University, Faculty of Educational Sciences, Turkey (ORCID: 0000-0002-3529-688X)
}

\begin{abstract}
Professional development studies have contributed to teachers' professional motivation and student success. Therefore, professional development activities must take into account the needs and interests of the stakeholders involved in education circles. The current study aims to examine Turkish language teachers' past experiences with professional development and determine their perceptions of and expectations from professional development. The study adopted a phenomenological approach. The data were collected from interviews conducted with 38 Turkish language teachers working in Bursa. The data were analyzed qualitatively using content analysis. Findings showed that the Turkish language teachers were keen to participate in the professional development activities held by the Ministry of National Education (MONE) in Turkey, but that their past experiences were not satisfactory. The study investigates professional development considering many aspects and proposes suggestions based on the findings.
\end{abstract}

Keywords: Professional development; Teacher education; Turkish language teaching

Article History: Submitted 28 October 2020; Revised 26 January 2021; Published online 11 February 2021

\section{Introduction}

Adapting to the rapid changes in technology and knowledge production in the 21st century, namely the information age, is becoming more difficult yet necessary. In the current century, knowledge and technology are considered to be the dominant power affecting individual and social lives. In societies that have undergone the information age, the definition of the teaching profession has gradually changed, and education has been demonopolized contrary to the industrial societies where mass media have no active role. The social and technological transformation has imposed an "educational" function on the institutions, which are considered to be information resources of society, and which enable individuals to learn. New media such as the Internet, television, newspapers, and magazines have challenged and competed against the mainstream power assigned to the teaching profession (Özkan, 2011). Teachers, aiming to educate 21st-century learners who take for granted and live on these new sources of information, need to bring the most current and accurate information into the class. They should also realize their

Address of Corresponding Author

Hatice Yılmaz Yurtsever, PhD, Bursa Uludağ University, Faculty of Education, Görükle Campus 16059 Nilüfer, Bursa, Turkey.

$\triangle$ hyurtseven@uludag.edu.tr

How to cite: Yurtseven-Yilmaz, H. \& Sever, S. (2021). A professional development analysis for Turkish language teachers: What did they expect? What have they found?. Journal of Pedagogical Research, 5(1), 88-113. http:// dx.doi.org/10.33902/JPR.2021067243 
deficiencies in time and have the motivation to develop. The success of the education system heavily depends on the teachers' qualifications as the operators of this system. The world's best school systems have to make the right people teachers and transform them into effective teachers (McKinsey Report, 2007). It should be noted that even if education systems, policies, curricula, course materials, and learning platforms are changed, the intended success in education will not be achieved unless teachers accommodate these changes. Therefore, teachers, who are assigned significant duties to become models and guides for the acquisition of the 21st-century skills, need to undergo continuous development compatible with the needs and expectations of the time, to meet high standards, and to help develop an advanced level of competence (Mustan, 2002; Paker, 2008). In-service teachers' professional development regarding teaching skills, field knowledge, and educational approaches must be maintained by both self- and institutional training.

\subsection{Professional Development}

We encounter various terms coined in the literature for professional development (PD). These include continuing education, professional development, professional learning, in-service training, continuous professional development, career-related continuous learning, professional advancement, and personnel development. "Professional development, in a broad sense, refers to the development of a person in his or her professional role" (Villegas-Reimers, 2003, p. 11). People strive for betterment in their professions through self-training and institutional support for development. The teaching profession aims to enhance students' learning by improving teacher qualifications with professional development (Craft, 2000; Drage, 2010).

Professional development is a process that helps teachers improve their professional knowledge, skills, and attitudes; thus, it promotes students' learning (Guskey, 2000). Learner success is the strongest motive for teachers to continue professional development. Research has revealed that high-quality professional development can change teacher practices and positively affect student learning (Borko \& Putnam, 1995; Darling-Hammond, 2000; Desimone et al.,2005; Yoon et al.,2007). It is known that students learning in a class with a low-achieving teacher become low-achievers while students with a high-achieving teacher turn out to be high-achievers. Teachers increase their success to the extent that they participate in professional development, which simultaneously increases student achievement.

Professional development includes both formal and informal experiences (Ganser, 2000). Formal learning opportunities consist of learning environments with a structured program such as postgraduate courses or compulsory professional development (Feiman-Nemser, 2001). Such experiences represent conventional practices of professional development. Formal learning opportunities enable teachers to upgrade their knowledge and skills with workshops and courses. Experts generally think that the information provided through these short-term events will be put into practice. On the other hand, informal learning opportunities do not follow a structured program and are not restricted to specific educational settings. They include individual activities such as reading and classroom observations as well as collaborative activities such as interviews with colleagues and parents, mentoring activities, teacher networks, and workgroups (FeimanNemser, 2001; Desimone, 2009; Richter et al.,2014).

There are different views on professional development models (Borko \& Putnam, 1995; Guskey, 2000; Sparks \& Loucks-Horsley, 2007). Craft (2000) looks at professional development from several angles including "purposes", "location", "length", "methods", and "levels of impact" (p. 17). In her model, the purposes consist of staff/group performance, individual job performance, career development, professional knowledge, and personal education. Location refers to off-site professional development, school-based professional development, and school-focused professional development. Length includes long opportunities (1-3 years), short opportunities (220 days), and incidental opportunities (1-2 days). Methods are action research, working with colleagues, visits, and placements, the creative use of information and communication technology (ICT), and job definition/comparison. Lastly, levels of impact are split into staff-team-department 
performance, career development, and professional knowledge. Examining professional development models, we notice that value attribution and teacher identities shape these models. Those who consider teachers as passive practitioners or technicians opt for the course model for professional development, while those who see teachers as thinkers who undergo selfdevelopment appear to prefer guided self-development, workgroups, and counseling (Bümen et al., 2012).

\subsubsection{Professional development of teachers in Turkey}

The professional development programs for teachers in Turkey are locally prepared and implemented each year by the provincial directorates of national education in a unit called the Professional Development Support and Monitoring Department within the body of the Ministry of National Education General Directorate of Teacher Training and Development. Besides, it is observed that the MONE has recently reduced the number of face-to-face training courses. Professional development practices have begun to be implemented by non-governmental organizations or TÜBİTAK (the Scientific and Technological Research Council of Turkey) with their training and project activities (Günel \& Tanriverdi, 2014).

The significance of professional development has been stated in state policy by laws and regulations (the Basic Law of National Education No. 1739, Civil Service Law No. 657, the Organization and Duties of the Ministry of National Education Law No. 3797, and the In-service Training Department of the Ministry of National Education). When official documents such as the tenth development plan (Republic of Turkey Ministry of Development, 2013), the eleventh development plan (Strategy and Budget Department of the President of the Republic of Turkey, 2019), National Education Quality Framework (MONE, 2015a), and the MONE Strategic Plan (MONE Strategy Development Directorate, 2015b; 2019a) that shape the near future are analyzed, it is evident that the development of the basic skills of employees is emphasized, and that professional development has been prioritized. For example, education policies in the tenth (2013) and eleventh development plans (2019) aim to make the teaching profession more attractive, organizing the teacher training and professional development systems in a way that continually encourages personal and professional development for teachers and promotes career development and performance, and revising the content of professional development in a way that responds to the current needs of teachers and school administrators. Besides, the 2019-2023 MONE Strategic Plan aims to create a new understanding of professional development, a novel system, and a model to support the development of teachers and school administrators.

Approximately $45 \%$ of teachers in Turkey are under the age of 34 years, which is an age group consisting of young adults. On the other hand, only $11 \%$ of teachers are aged 50 or older. Compared to other OECD countries, Turkey's teacher population is considered to be quite young (Eğitim Bir-Sen, 2016, p. 170). When considering that younger teachers need more training, professional development activities in Turkey appear to be essential.

Policy documents are highly concerned with professional development. Almost all educational research recommends it as a solution to problems in professional endeavors. However, the success of professional development practices in Turkey is a matter of debate. Studies conducted by the Ministry of National Education $(2006 ; 2010)$ revealed that teachers' need for professional development was not properly met. Half of the training activities targeted occupational knowledge-based professional development, and the substantial expenditure on professional development did not yield a profitable result. There have been a large number of studies on inservice training held by the MONE (Arıbaş, Kartal, \& Çağlar, 2012; Arık, 2017; Avc1, 2018; Balkız, 2013; Baştürk, 2012; Büyükcan, 2008; Çiftci, 2008; Durmuş, 2013; Güneş, 2006; Karasolak, Tanrıseven, \& Konokman, 2013; Kaya et al., 2013; Nartgün, 2006; Öz, 2012; Özen, 2006; Sezer, 2006; Türkhan, 2008; Uçar, 2005; Ulus, 2009; Ülker, 2009; Veyis, 2012; Yıldırım, 2012; Yıldız \& Arıbaş, 2012). These studies highlighted various problems related to in-service training, including the available training programs being unresponsive to teachers' current needs, the duration of the 
programs, physical environmental conditions, the inadequacy of the educational equipment and accommodation facilities, inconvenient timing, and the lack of trainers (Yurtseven Yilmaz \& Gülçiçek Esen, 2015).

International studies also illustrated that the work on professional development in Turkey was not at the desired level of quality. Based on the 2015 Teaching and Learning International Survey (TALIS), teachers mostly attended educational conferences or seminars (about $72 \%$ ) and courses/workshops (64\%). Nevertheless, only about $25 \%$ of them believed that these activities made an impact on their professional development. While $45 \%$ of teachers preferred participating in more professional development activities, 55\% appeared to be reluctant. Moreover, Büyüköztürk et al. (2010) noted that teachers participated the least in activities that they considered to be the most useful for their professional development. According to the 2015 PISA report (Taş et al., 2016), the rate of teacher participation in professional development in Turkey was less than half that of the OECD average (OECD average: $509 \%$ and Turkey average: $24 \%$ ). The 2018 TALIS asked teachers whether the professional development activities they attended had a positive impact on their teaching practices. In the OECD average, $81.8 \%$ of teachers indicated that participation in professional development activities positively impacted their teaching practices, while this ratio was $71.8 \%$ for Turkey. Turkey was the sixth lowest country in terms of the percentage of teachers stating that professional development activities had positive effects on their teaching practices (Karip, 2019).

In terms of Turkish language teachers' responsibility, in primary and secondary schools, one of the most critical factors affecting success in learning other subjects is the first language teaching. During the education process, the objective is to improve students' comprehension and expression skills and to provide students with language awareness and sensitivity. Öz (2011) reported that students reading fast and accurately understand what they read, have an extensive vocabulary and mastery in oral and written language use, and are more likely to succeed in other subjects; therefore, the Turkish language course should not be underestimated. Sever (2001) noted that rational individuals, who can communicate effectively in the written language, develop understanding, expressive skills and critical thinking skills, and make autonomous decisions, can become a constructive and creative part of their cultural environment (p. 14). In the educational system, the responsibility of teaching the desired behaviors falls primarily on teachers teaching children's mother tongue. According to the MONE (2008), the Turkish language teacher should be able to prepare lesson plans for Turkish language education, organize learning environments, and use course tools and technological resources appropriate for Turkish language education in addition to improving students' language skills. Turkish language teachers are expected to have qualifications such as preparing activities for students with learning difficulties and special education needs, utilizing assessment and evaluation tools/methods, cooperating with families, and manifesting leadership skills for societies. Besides, Turkish language teachers should realize that their personal and professional development determines their own professional competencies. The objectives of the curriculum of the Turkish Language Teaching Program (MONE, 2018) refer to particular qualifications for Turkish language teachers such as that they should have high-level thinking skills (comprehension, analysis, synthesis, evaluation, reflective thinking, problem solving, etc.) and reflect them in their practices in the classroom.

Professional development programs designed to meet the needs of in-service Turkish language teachers who are expected to have this knowledge, and these skills and attitudes, will improve the quality of Turkish education. Hence, conducting a situation analysis and identifying teachers' expectations, wishes, and needs are necessary. It generates a significant gap in education when teachers are put in a position to develop personally and professionally without providing them with the activities to fulfill their needs, expectations, and wishes. This gap can be bridged by integrating the developments in the teaching profession with general and specific field competencies and by regularly training Turkish language teachers who teach different levels during their careers. 
Considering the abovementioned case, we aim to answer the following questions.

What are Turkish language teachers' views on their past professional development experiences?

What are Turkish language teachers' opinions about professional development?

What are Turkish language teachers' expectations from professional development activities?

\section{Method}

\subsection{Research Design}

This study was designed as phenomenological research since it aimed to determine Turkish language teachers' views on professional development based on their experiences. Phenomenological studies describe the common meaning and experiences of a phenomenon or concept that several individuals share (Creswell, 2015). The use of in-depth interviews allows the researcher to elicit the reactions and perspectives of people who share common experiences (Fraenkel \& Wallen, 2009).

\subsection{Study Group}

We worked with a group of Turkish language teachers working in Bursa for the interviews, since it was not convenient to access and interview all Turkish language teachers in the area. We applied the purposeful sampling method. The study group consisted of Turkish language teachers with permanent positions in the three biggest districts of Bursa. The sampling was carried out among teachers who had participated in professional development activities held by the MONE on a minimum of three occasions. Non-probability sampling allows researchers to benefit from the unique knowledge or experience of certain groups meeting specific criteria to study the vibrant nature of a particular phenomenon. The selected sample is considered to serve the purpose of the study (Lune \& Berg, 2017; Merriam \& Tisdell, 2015; Patton, 2014). The researcher aimed to gather in-depth information on professional development by interviewing Turkish language teachers who had participated in professional development activities on at least three occasions.

The interviews continued until data saturation was reached. In qualitative research, data collection ends when no new or additional information is received, that is, when data saturation is achieved (Merriam \& Tisdell, 2015). A total of 38 Turkish teachers holding permanent positions were interviewed. 35 teachers are graduates of Education Faculties. 27 of them graduated from Turkish Language Teaching, 3 from Turkish Language and Literature Teaching, and 1 from German Language Teaching departments. 3 teachers are graduates of the Faculty of Literature, Department of Turkish Language and Literature. None of the teachers had received postgraduate education.

Table 1

Teachers' years of experience in the profession

\begin{tabular}{cccccc}
\hline $\begin{array}{c}\text { Years of } \\
\text { experience }\end{array}$ & $\begin{array}{c}\text { Less than five } \\
\text { years }\end{array}$ & $5-10$ years & $11-15$ years & $16-20$ years & $\begin{array}{c}\text { More than } 20 \\
\text { years }\end{array}$ \\
\hline$f$ & 3 & 12 & 11 & 7 & 5 \\
\hline$\%$ & $8 \%$ & $31.5 \%$ & $29 \%$ & $18.5 \%$ & $13 \%$ \\
\hline
\end{tabular}

As seen above, teachers from each year category were included in the interview process. More than half of the Turkish teachers we interviewed had 5 to 15 years of professional experience. The number of teachers with five years of experience or less comprised the lowest percentage. The more years of work experience teachers had, the more in-service training courses they had attended. Considering this formula, it was essential for the study to include more teachers with more years of work experience in the profession. 


\subsection{Data Collection and Analysis}

The interview method was used in order to make a more in-depth analysis of Turkish language teachers' views on professional development. Interviews can provide in-depth information about a particular research topic or question. Through interviews, we aim to understand the subtle meanings in individuals' experiences, attitudes, opinions, intentions, comments, perceptions, and reactions (Yıldırım \& Şimşek, 2011, p. 120). Semi-structured interviews were conducted due to their analytic advantages such as ease of analysis, opportunity for interviewees to express themselves, and obtaining in-depth information (Büyüköztürk et al.,2012). The interviews were carried out individually. Karasar (2014) describes individual interviews, where there are no participants other than the interview source and the researcher, as an effective way to obtain personalized information.

A semi-structured interview form was prepared for the interviews. The interview questions, consisting of 31 items, were developed by the researcher. Experts (one assessment and evaluation specialist, one language expert, and one professional development specialist) were consulted about the questions, which resulted in some alterations. As a pilot application, 3 Turkish language teachers were interviewed before finalizing the interview form. Content validity was ensured with both expert opinions and the pilot application.

Questions in the interview form were grouped into three categories, namely professional information, professional development background, and views on professional development. The professional information category included three questions determining teachers' professional backgrounds. The 14 questions in the category of professional development background aimed to reveal the teachers' status regarding their participation in professional development activities. The last category included ten questions to gather the teachers' opinions about professional development processes.

Following the finalization of the interview form, interviews were conducted at a convenient time and place. The teachers were interviewed in their work environment in the spring semester of the 2017-2018 academic year, following their work schedules. Before each interview, the researcher explained the purpose of the research, how and where the data would be used, the approximate duration of the interview, and confidentiality matters, and provided the teachers with informed consent forms. Interviews were recorded with a voice recorder with teachers' permission. The interviews lasted between 15 and 50 minutes. The recordings were transcribed by the researcher, resulting in about 120 pages of raw data. The data were analyzed through content analysis, and the codes, categories, and themes were created. Content analysis is defined as gathering similar data around particular concepts and themes and organizing them in a way that the reader can understand (Yıldırım \& Şimşek, 2011). The themes and categories of the research findings are as follows:

Professional development background. Participation, meeting educational needs, content, duration, environments, trainers, methods and techniques, assessment and evaluation, and needs analysis.

Views on professional development. The necessity of professional development, trainers, timing, participation status, organization, and local differences.

Voice recordings were examined individually, and the cycle of review yielded categories (themes and sub-themes) for each question. Following the identification of the themes and categories, the data were screened to determine the frequency of each theme occurring overtly and covertly. In content analysis, intercoder reliability requires different coders to encode the same text in the same way, or the same encoder to encode the same text in the same way at different times (Bilgin, 2014). It is established as a condition of objectivity for reliability that the interpretation of categories does not vary from coder to coder or at two different coding times (Tavşancll \& Aslan, 2001). The researcher re-coded five questions in the semi-structured interview form three months later. The agreement between these two codes was $97 \%$ when the interrater agreement formula, Agreement/( Agreement + Disagreement) x 100, suggested by Miles \& Huberman (1994) was 
applied. The teacher interviews were labeled with the letter ' $\mathrm{T}$,' and individual interviews were specified as 'T1, T2, T3' based on the order of interviews.

\section{Results}

The Turkish language teachers' evaluation of professional development activities they had attended was categorized as 'professional development background,' and the category called 'views on professional development' included their expectations and views on the factors affecting professional development. Professional development was abbreviated as PD.

\subsection{Professional Development Background}

\subsubsection{Status of participation in professional development activities}

The interviewees were asked about the names and number of PD activities they had attended so far. All teachers stated that they could not remember most of the PD activities. Besides, they referred to their attendance in compulsory PD activities. For instance, T18 indicated that "I have definitely participated. I cannot remember now. I have my certificates, but I need to go through them to remember, as it has been 16 years...". Another teacher, T37 asserted that "We attended compulsory PD activities as assigned by the school administration. There was the Fatih Project. I do not really remember the names of the rest."

The teachers were also asked whether the PD activities attended were related to Turkish language education. Twelve of them stated that they had not received training in their field. Six teachers asserted that they had participated in field-related training, whereas 20 answered that they could not remember. The teachers generally stated that they had had occupational knowledge-based training. For instance, T15 indicated that "We have not received any fieldrelated training. We only attended the compulsory ones. The training courses were not so productive, obviously, otherwise I would remember them now." As another example, T19 pointed out:

I have attended both field-related and out-of-field training. For instance, there was first-aid training as out-of-field training. Many were field-related. When the system changes, they definitely get us to attend in-service training. There were many, though I do not remember how many.

According to the findings, some of the teachers participated in occupational knowledge-based compulsory training. The common point of both the teachers who stated that they had received training, and those stating that they had not received training in their field, is that the training courses were not included in their memories. Teachers were not able to remember adequately either the names of the training courses or their content. They kept the participation certificates in their files as proof of their attendance at the training sessions.

\subsubsection{Extent to which PD activities met teachers' educational needs}

We asked the Turkish language teachers participating in our study (38), "Do you think the PD activities you attended met your educational needs?" The responses were grouped and are presented in Table 2 below.

Table 2

Teachers' views regarding the extent to which professional development activities met their educational needs

\begin{tabular}{lc}
\hline Teachers' views & $f$ \\
\hline Some of them met my educational needs. & 2 \\
They met my educational needs. & 2 \\
They did not meet my educational needs. & 34 \\
\hline
\end{tabular}

Two of the teachers stated that the PD activities met their educational needs. Two teachers, on the other hand, asserted that only some of them met their needs. T6 and T18 asserted that respectively: 
We cannot attend most of them, but there are some goal-oriented ones. We do not have available time for training. The training courses I have attended definitely met my educational needs. I mean that the training sessions achieved their goal. (T6)

Some met my needs, and some did not. For example, we have had a seminar about first-aid. Now, I cannot recall anything from that seminar. I mean, we have been to that seminar, but I remember very little of it. (T18)

Thirty-four of the teachers responded that the PD activities that they have attended during their career did not meet their educational needs. For instance, T10 remarked that "I do not think the PD activities met my educational needs. This is because the topics of the activities were things that we already knew. We have not found anything that would improve us." Similarly, two other teachers pointed out:

Not entirely. For instance, there was a training course for the use of smartboards. The smartboards would not function, and we had an imaginary practice during the training. Well, yes, they (PD activities) did not really meet my educational needs. (T14)

No- because the training is good on paper, but it fails in the practice phase. We were given training in computer education. The teacher had a computer while we had no computers. How could this be of help? What is the point if we do not have a chance to practice? (T31)

The majority stated that the professional development activities they participated in did not achieve their purpose. The reasons for this are the repetition of what is known, the unsuitability or inadequacy of the educational environments and tools for adult education, and the fact that the activities were focused on knowledge transfer. It is also noteworthy that one of the two teachers, who thought that the activities met their needs, stated that although she thought there were good quality training courses, she did not participate in them.

\subsubsection{Extent to which the content of professional development activities was practice-oriented}

The teachers were asked the following questions: "Do you think the PD activities you have attended were practice-oriented? Were you able to transfer your learning to your practice in the class?" The responses are displayed in Table 3.

Table 3

Teachers' views on the extent to which the content of professional development activities was practiceoriented

\begin{tabular}{lc}
\hline Teachers' views & $f$ \\
\hline Practice-oriented & 2 \\
Not practice-oriented & 36 \\
\hline
\end{tabular}

Only two of the teachers stated that the PD activities attended were practice-oriented. The rest (36) asserted that the activities were not practice-oriented. T25 asserted that "I mean, they are often theory-oriented. If there are practice-oriented ones, we are more than happy and willing to attend. For example, we have not done any practice in first-aid training. They showed us, and we simply watched." Another participant, T3 indicated that "The content was often not unfamiliar to us. We went back to listening to the same things so there were no practical changes for me in the class." As a final example, T31 pointed out:

Some were practice-oriented. Even though I was not satisfied with the quality of the training, being in a different environment with different teachers, learning from their practices, and adapting something new to our own practices, of course, contribute to our lives.

Most Turkish teachers stated that the professional development activities they participated in during their term of duty were theory-based and knowledge-based. They generally tried to learn something by reading the slide presentations that the trainer projected on the board. 


\subsubsection{Duration of professional development activities}

The participants were asked the following question: "Was the duration of the PD activities you have attended adequate for the topics covered?" Table 4 shows the responses.

Table 4

Teachers' views on the duration of professional development activities

\begin{tabular}{lc}
\hline Teachers' views & $f$ \\
\hline The duration was not adequate. & 16 \\
The duration was adequate. & 22 \\
\hline
\end{tabular}

Twenty-two of the teachers responded that the duration of the PD activities attended was adequate for the topics covered. In this sense, T4 remarked that "They are often around 40-45 minutes in duration. Of course, the duration depends on the nature of the training, but it is enough to cover (the intended topics). It is enough time since trainers use presentation slides anyway." In a similar manner, T19 underlined that "The duration is not the problem. The problem is the delivery of the content. The length of the training does not matter."

The teachers who considered that the duration was adequate focused on a particular point. Regardless of the duration issue, teachers stated that the training was generally restricted to a short period of time (also due to teachers' pressure) by trainers. As T24 pointed out:

They say the training starts at 9 am and ends at $5 \mathrm{pm}$. However, the trainers suggest speeding it up and say, "there are some trivial topics we can skip, and we will finish at 1 pm". The participants also want to go home early. The trainers do not believe in their job and consider it to be a chore. It is a top-down order by which they are assigned to educate 300 people at once, and they end up loathing it. In this way, they cut off hours from the training.

Fifteen of the teachers considered that the in-service training duration was not enough to cover the intended topics. T32 remarked that "It is not adequate. Generally, the intended topic coverage is too extensive for the allocated time, so the trainers have to skip some topics or speed through the topics." Another teacher, T31 asserted that:

Some were poorly timed. There was too much or too little time. They plan a 120-minute training for something that can be delivered in 40 minutes, which is a waste of time and labor, and a loss in every sense.

Regarding the durations, all teachers agreed that the times written on paper were often not followed during the practice. Sometimes, the reason for this was the unwilling or unprepared trainers, sometimes the teachers' fatigue or unwillingness, and sometimes the timing that was not suitable for the subject.

\subsubsection{Physical Environmental Conditions of Professional Development Activities}

The teachers were asked about the physical environmental conditions of the PD activities they had attended, and the responses are shown in Table 5.

Table 5

Teachers' views on the physical environmental conditions of professional development activities

\begin{tabular}{lc}
\hline Teachers' views & $f$ \\
\hline Physical conditions were favorable. & 24 \\
Some had favorable physical conditions. Some had unfavorable physical conditions. & 6 \\
Physical conditions were unfavorable. & 8 \\
\hline
\end{tabular}

Twenty-four of the teachers reported that the physical conditions where training took place were favorable. For instance, T4 remarked:

Training sessions are often held in conference halls at the schools, or else teachers are asked to go to the district centers. For the former ones, the physical conditions vary depending on the school 
facilities. The ones in the district centers are held in large conference halls open to everyone, and these, of course, are organized more carefully.

Six of the teachers noted that some of the educational events they attended had favorable physical conditions while others did not. For example, T25 pointed out:

Not all were favorable. First of all, some of them are held in very crowded places. They gather you in a big hall. There is a small screen. You cannot even see the screen from a distance sometimes. I do not think the conditions are very favorable. There must be smaller groups.

Similarly, T16 expressed that, "Yes, some of them were nice places, such as conference halls. But many of them were in a classroom or in a very cold or hot place. There was even one held in the cafeteria."

Eight of the teachers stated that the physical conditions where the activities took place were not favorable. For instance, T15 assertad that:

They are not favorable. For example, we are crammed into multi-purpose halls. The places are very stuffy, hot, airless, and stifling, or there is too much noise, or too many people, which becomes a problem. I mean, we had such difficulties in the training courses that I remember.

The physical environmental conditions of professional development activities that were held were found appropriate by the majority of the teachers. Teachers wanted to receive education in their own schools and did not want to go to another school or hall. Teachers cared more about the proximity of the environment than its appropriateness. The most common complaint of teachers was that the environments were crowded. They stated that there was noise in the training sessions carried out in crowded environments, it was difficult to focus attention, and so the training did not serve its purpose. Another issue that was mentioned about the environments was the ineffective use of educational tools. Projection was predominantly used in the training courses. Smart boards, which have been popularized by the Ministry of National Education in recent years, were also used frequently in the training courses. However, with these tools, only the slides were projected on the screen, and teachers were waiting for the trainers to read the slides. In some examples, it was stated that the transparencies were not read by the trainer and even that this task was left to the participants.

\subsubsection{Qualifications of the trainers providing professional development activities}

The teachers were asked whether they thought the trainers of the PD activities were experts in their fields, and the responses are given in the following table (Table 6).

Table 6

Teachers' views regarding the expertise of the trainers providing professional development training

\begin{tabular}{lc} 
Teachers' views & $f$ \\
\hline They had sufficient expertise. & 13
\end{tabular}

Some of them had sufficient expertise. Some of them had insufficient expertise. 14

They had insufficient expertise.

13 out of 38 teachers considered trainers' expertise to be sufficient. T1 expressed that, "I think they had sufficient expertise. They have been involved in the education sector for many years too. But I think they are not entirely sure whether what they tell us is productive or not." Fourteen of the teachers thought that some of the trainers were experts in their fields, and some were not. For instance, T3 stated that, "It would be wrong to speak for all of them, but some had sufficient expertise. Some got us to listen to them while some sent us to sleep."

On the other hand, 11 teachers suggested that the trainers did not have sufficient expertise. For instance, T16 explained that, "They had insufficient expertise. I mean, they are teachers just like us. Maybe they have had the education we have, yet they have not completed a higher level of education. Sometimes they give evasive answers to our questions." Similarly, T23 asserted that: 
They had insufficient expertise. It is generally the case that people whom I would not even consider having much classroom management do this job. I have come across trainers whose voices we could hardly hear, who had difficulty speaking behind the stand and who could not make eye contact with the audience. Maybe it was just my case; I do not know.

Teachers often emphasized the reluctance of trainers. Trainers were tired of constantly explaining the same training to different groups. In addition, it is understood that there were trainers who were inexperienced or needed training in communication skills and adult education. Teachers complained about trainers who treated them like children or belittled them. Teachers were particularly bothered by the fact that academics ignored the knowledge and experience of teachers and gave advice about the practice by telling them theoretical information even though they did not have teaching experience.

\subsubsection{Methods and techniques used in professional development activities}

Teachers were also asked whether suitable methods and techniques were used in the PD activities. They were also asked to elicit some of these methods and techniques. The frequency values based on the teachers' responses are presented in Table 7.

Table 7

Methods and techniques used in professional development activities

\begin{tabular}{lc}
\hline Teachers' views & $f$ \\
\hline Lecture & 38 \\
Question and Answer & 13 \\
Games & 3 \\
Modeling & 2 \\
Brainstorming & 1 \\
Drama & 1 \\
\hline
\end{tabular}

The responses showed that the most frequently used methods to which teachers referred were lecture and question and answer. T17 stated that, "It was generally lecturing and questions and answers. I do not remember anything else." Another teacher, T29 expressed that, "Lecturing, question and answer, asking us questions to see if we have an idea. That is often the case. It is like lecturing first, and then answering our questions or asking what we think about a particular question."

Teachers also mentioned games. However, it was not clear whether the method or technique referred to as a game was role-playing, dramatization, or drama. Only one teacher clearly stated that drama was used. For instance, T6 stated that, "I think the methods and techniques were used effectively since we were involved in the games. There was no other method anyway. We played games together." Similarly, T22 expressed that, "Some were individual work, while drama activities were in groups. The rest was lecturing." In addition to these responses, two teachers referred modeling. For example, T20 asserted that, "Lectures are frequently used, but I remember that mannequins were used in first-aid training for practice. Computer education was carried out with computers." Besies, only one teacher indicated that brainstorming as, "Presentations are quite common anyway. But some people utilized question and answer and brainstorming methods."

The most preferred method in professional development activities was the method of lecture, in which training was effective. After the trainers conveyed information to the participants with this method, they used the question-answer technique to measure their understanding. In addition, the modeling method was used in practical training, such as first aid and computer training. Teachers remembered better the activities using different methods. Training where games were played or the participants were active was the first to come to mind.

\subsubsection{Assessment and evaluation in professional development activities}

The Turkish language teachers were asked whether assessment and evaluation were implemented at the end of the PD activities. Table 8 presents several teacher responses. 
Table 8

Teachers' views on assessment and evaluation implemented in professional development activities

\begin{tabular}{lc}
\hline Teachers' views & $f$ \\
\hline Assessment and evaluation were implemented. & 18 \\
Assessment and evaluation were implemented in some of them. & 10 \\
Assessment and evaluation were not implemented. & 10 \\
\hline
\end{tabular}

Eighteen of the 38 Turkish language teachers stated that assessment and evaluation were conducted at the end of the PD activities in which they participated. In this regard, T4 stated that, "Assessment and evaluation are conducted. They are things we usually complete elsewhere and submit to satisfy people." Two other teachers, T20 and T33 pointed out that:

Yes, there is an exam for each training course. It is absolutely necessary to take the exam to get a certificate. No certificate is delivered without taking an examination, but the assessments are not really reliable. One can pass the exam even if $\mathrm{s} /$ he never follows the training. People cheat in some of the tests. The trainer gives the answers sometimes. (T20)

Yes. There is assessment and evaluation. We were tested on topics we had no idea about, so we helped each other, like 'the answer to question 35 is option $\mathrm{A}^{\prime}$. We did and assessed the test ourselves. We corrected our mistakes on the test. (T33)

Ten of the teachers pointed out that some of the PD activities were assessed at the end of the training in which they participated, while others were not. For instance, T3 stated that, "One or two of them (PD training courses) applied measurement, but most of them do not do it."

10 Turkish language teachers stated that assessment and evaluation were not implemented during PD activities. For example, T8 stated that "There was no evaluation. But we received a certificate that I have kept."

It is understood from the teachers' opinions that some of the professional development activities were assessed, and some were not. Teachers drew attention to the quality of the evaluations made. They stated that these assessments and evaluations were made without any seriousness at the end of the process. They were not realistic and remained only on paper.

\subsubsection{Determining professional development needs of Turkish language teachers}

Following the scope of the current study, the teachers were asked, 'did the MONE or its affiliated units consult your opinion to determine your professional development needs during your teaching years?' The responses can be seen in Table 9.

Table 9

Teachers' views on determining professional development needs

\begin{tabular}{lc}
\hline Teachers' views & $f$ \\
\hline I was consulted for my opinion. & 17 \\
I was not consulted for my opinion. & 21 \\
\hline
\end{tabular}

As seen in Table 9, 21 of the teachers reported that they were not consulted for their opinions on their professional development needs by the MONE or its affiliated units. For instance, T2 pointed out:

We were not asked anything. They did not identify our needs and deficiencies. There was an attempt to introduce a performance-based system, but it would have been better if we had first identified our shortcomings and then the system had been changed.

Seventeen of the Turkish language teachers expressed that they were consulted by the MONE or its units to determine their PD needs during their teaching career. In this sense, T15 stated, "Surveys are occasionally carried out, but nothing happens afterward. We did not get any kind of feedback.". Another teacher, T23 asserted that: 
There are some surveys, but I do not even think they look at them much. I do not want to express myself much in the community meetings anymore because, think about it, you have been a teacher for 15 years, and you have been telling the same things for 15 years, and you see that nothing has changed. Then, you think your word is not respected.

Almost half of the teachers stated that the MONE or its affiliated units did not consult them for their opinions to determine their professional development needs, while the other half stated that they were consulted. Teachers complained that they could not receive feedback even if they expressed their needs and wishes. For this reason, they thought that they were not given importance within the institution.

\subsection{Teachers' Views on Professional Development}

\subsubsection{The necessity of professional development}

Our participants were asked whether they considered professional development activities to be necessary for teachers. They were also asked to elaborate on the reasons for their responses. Thirtyseven of the teachers asserted that PD activities were needed for their professional development, whereas one teacher disagreed. T4 coded teacher who considered PD to be necessary responded as "Everything is changing, and we are trying to keep up with the changes. This generation has different wants and expectations. The parental profile varies. The student profile varies. Hence, our needs are increasing". Another teacher, T15, pointed out that:

Yes, it is necessary because the world is changing so fast. Of course, we do not go round in circles. We try to improve ourselves, but we still need training to keep up with the speed of change, because I do not base my teaching on my education that I received 14 years ago. Nor should I. Times are changing. The profiles of children are also changing. The learning environment is changing. The needs are changing. The government needs to increase the quality of education, exploring common ground for all teachers.

Examining the responses, we observed that teachers emphasized a discourse of "change". They wish to keep pace with the rapidly developing/changing world. The reason is that the factors affecting the quality of their work are inevitably a part of this change. As the key elements of education, students are growing up in the world informed about the current social and educational principles, which are different from the world where teachers were born and raised. Parents expect their children to be educated with the most current information and contemporary teaching approaches. Teachers are expected to accommodate this rapid change, develop in their field, and plan education by acting on this change. In order to actualize this adaptation, professional development activities are required. Only one of the teachers, T19, found the PD activities unnecessary:

They are not necessary. It would be so much better if they reached us via the Internet. Face-to-face education and the like, these are outdated. I mean, it is necessary to keep up with the times. They could do online education, which is so much more convenient. It could be when I am home, feeling ready to start training instead of calling me out here for training at 7 in the evening. What am I supposed to think about: the training or my hungry kid waiting for me at home?

As can be inferred from this response, the teacher who responded negatively about PD was not entirely against PD activities. T19, who had been working for 26 years, no longer cared about faceto-face training. S/he emphasized that people could use computers nowadays, hence online activities would be effective. Also, we understood from his/her previous responses that s/he was not satisfied with the PD activities s/he had attended during his/her teaching years.

\subsubsection{Trainers Providing professional development activities}

Teachers responded to the question, "who do you think should provide professional development training?", and Table 10 displays their responses. 
Table 10

Teachers' views on professional development trainers

\begin{tabular}{lc}
\hline Teachers' views & $f$ \\
\hline By experienced teachers & 7 \\
By experts in the field & 29 \\
By MONE trainers & 2 \\
\hline
\end{tabular}

As seen in Table 10, 29 of the teachers preferred the field experts to provide PD training. In this sense, T9 and T14 coded teachers expressed that respectively:

Well, I think training should be given by people at universities who are experts in their fields and engaged with students. I do not know if that is possible because academicians are generally interested in the academic aspect of the work. However, I think people who know both the academic dimension and are close to students should be giving instruction related to PD activities. (T9)

It (PD training) should be given by experts in this field. Apart from being an expert, a trainer should be good at teaching, that is, someone who has a great understanding of teaching practice. Knowing is not enough. Trainers should have the ability to speak and know what to tell and when. (T14)

Seven teachers stated that experienced teachers should conduct PD training. The responses of $\mathrm{T} 1$ and $\mathrm{T} 2$ were as:

I think training should be given by people who have many experiences in teaching. People who were involved in a classroom atmosphere for years and have gained experiences should train the teachers. Someone who has experienced being a teacher would know better. (T1)

Teachers should do it. Frankly, I agree with academics delivering PD training, but as we teachers are the ones in the implementation stage, it would be better if training revolved around us. We know best what we want, our shortcomings, and problems. To accommodate all these, I think it would be better if teachers involved in the implementation stage provided the PD training. (T2)

Two of the teachers stated that MONE trainers should provide PD training. As T24 pointed out:

The MONE needs to establish a unit for this. Of course, this needs human resources. I would like to take part in such a unit. I would be the teacher of that unit. I would have certain subjects to master; you cannot know everything after all. They would say "you are going to give seminars on these three topics next year," and I would prepare myself.

Despite giving different responses, all teachers shared the following common points. Trainers should:

1. be experts in the field, get teachers to trust their knowledge, be able to give satisfactory answers to teachers' questions,

2. have teaching experience, be aware of in-class problems, and offer realistic solutions to these problems when needed,

3. have the ability to teach, because knowledge alone is not enough,

4. have excellent communication skills, make eye contact and use facial expressions and gestures, and be good-humored, and

5. remember that they work with adults, and avoid treating participant teachers like children.

\subsubsection{Timing of professional development activities}

The participants of the study were asked, "when should professional development training be held?", and the responses were grouped into two categories (see Table 11).

Table 11

Teachers' views on timing of professional development activities

\begin{tabular}{lc}
\hline Teachers' views & $f$ \\
\hline During the seminar (June and September) periods & 24 \\
During the seminar periods and in the academic year & 14 \\
\hline
\end{tabular}


Twenty-four teachers suggested that PD training should be held during the seminar periods at the beginning of September and the end of June. T3 and T16 coded teachers pointed out:

When the training overlaps with our classes, it gets exhausting, and we just want to leave. We are quite reluctant. We already feel exhausted after 7 - 8 hours of teaching. I think it is better to hold the training in the seminar periods, as we have more spare time in those periods. (T3)

I think it should be during the seminar periods in June and September. During the year, teachers find it troubling to leave after school to go to the schools where seminars are held. We have nothing to do and are burdened with unnecessary matters during June and September. Seminars should be held in these months so that it would not be a waste of time for us. (T16)

Fourteen of the teachers stated that PD activities could be held both during the seminar periods in September and June and in the academic year. For instance, T14 expressed that, "It would be good if seminars took place in June and September, or maybe throughout the year."

The last two weeks of June and the first two weeks of September are reserved by the MONE for teachers' professional development activities. For this reason, most of the teachers wanted professional development activities to be planned in these periods. Thus, they believed that this 4week period would be more efficient. 14 teachers stated that such activities could be planned during the seminar period and in the academic year. Teachers only wanted to participate in professional development activities when they were not physically and mentally tired.

\subsubsection{Participation status of professional development activities}

We asked the teachers whether participation in professional development activities should be compulsory or voluntary. They were also asked to address the reasons. Table 12 shows their responses.

Table 12

Teachers' views on participation status of professional development activities

\begin{tabular}{lc}
\hline Teachers' views & $f$ \\
\hline Voluntary & 12 \\
Compulsory & 17 \\
Both voluntary and compulsory & 9 \\
\hline
\end{tabular}

Seventeen teachers suggested that it should be compulsory to attend PD activities. For instance, T3 stated that, "Participation should be compulsory. $80 \%$ would not participate if it were voluntary. Even if there were a subject I was interested in, I would say "geez, who is gonna go now!" Similarly, T4 pointed out that:

Participation must be compulsory. Everyone needs training. Participation in PD cannot be on a voluntary basis because everything is changing, and we need to change too. If participation were voluntary, only 10 out of 100 people would attend. However, if we make it compulsory, we can create a developing society.

On the other hand, 12 teachers favored voluntary participation in PD activities. As T5 stated that:

It can be on a voluntary basis because otherwise, it will not serve its purpose. People do not want to listen and shut down. If it was for me, it could have been compulsory, but I suppose it would work better if it was voluntary participation.

Nine of the teachers stated that participation should be both compulsory and voluntary. T10 and T31 coded teachers explained that:

It should be on a voluntary basis, but in some cases, participation should be mandatory because teachers can really be reluctant. I think it should be compulsory to participate when the PD training is about essential matters, such as when it is about our specialized field because, you know, not everyone is the same. (T10) 
The majority of the training should be on a voluntary basis, but we should also have some compulsory training, as we have colleagues who are not open to development. They need to keep up with progress. Students constantly learn, and they learn about researching more than we do. We should find a way to keep up with their pace. Therefore, some training must be compulsory. (T31)

According to teachers, learning happens more easily in activities they participate in voluntarily; such activities work better. However, when activities are voluntarily, most teachers do not participate. For this reason, they thought that some activities should be compulsory. Otherwise, they stated that a standard could not be achieved in terms of teachers' qualifications.

\subsubsection{Planning of professional development activities}

Regarding the planning of PD activities, the teachers were asked, "where should the planning of professional development take place? (central / province / district / school etc.)", and the answers were as follows (see Table 13):

Table 13

Teachers' views on planning of PD activities

\begin{tabular}{lc}
\hline Teachers' views & $f$ \\
\hline At a local level (province, district, school) & 23 \\
At a central level (Ministry) & 2 \\
Both & 13 \\
\hline
\end{tabular}

Table 13 illustrates that 23 teachers preferred the PD activities to be managed at a local level. The responses referring to provinces, districts, and schools were grouped and labeled as "local". T12 pointed out that:

I think provinces and districts should be responsible for the planning. I mean, the Ministry may impose a top-down approach. I think the Ministry may overlook the local differences. Certain areas may be the same, but there will also be differences. Therefore, I think planning should be at the local level.

On the other hand, 13 teachers thought that both central and local authorities should be held responsible for PD training. For instance, T4 asserted that, "It should be local, but in contact with the center. Local authorities should determine their training programs and then contact the center for support. A training course that is done in its own right fails badly." Similarly, T5 pointed out that:

From local to central, everyone should contribute their ideas, because people at the higher level hierarchically may not comprehend the problems of people at the lower level. Everyone's opinion should be regarded, from higher to lower levels. There should be a commission, consisting of people from every level.

Two teachers stated that PD activities should be centrally planned and managed. For instance, T3 stated that, "The center can manage the training courses. In this way, they would be more orderly and productive." Another teacher, T34 expressed that, "I think it would be better for everyone to undertake the same program coming directly from the center, under the same or at least similar conditions."

The teachers who thought that "the needs and problems of the regions are best known by those working in the region" stated that professional development activities should also be planned regionally. They thought that the regional needs were overlooked in the center's planning, i.e., the Ministry. Teachers who thought these two units should not act independently stated that common planning could be done.

\subsubsection{Local differences in professional development activities}

The Turkish language teachers were asked for their opinions on whether teachers' professional development needs differ across provinces/regions in Turkey (see Table 14). 
Table 14

Teachers' views on local differences in professional development activities

\begin{tabular}{lc}
\hline Teachers' views & $f$ \\
\hline There is a difference. & 34 \\
There is no difference. & 4 \\
\hline
\end{tabular}

Thirty-four teachers noted that there were differences in teachers' PD needs across provinces/regions in the country. T2 stated that, "Conditions are different across the country. Professional development needs of a teacher in Bursa (the west) and one in the east are not the same. Hence, the training courses should be individualized or localized." In a similar manner, T4 expressed that:

It depends on the provinces/regions. I was first assigned to Erzurum (the east). None of the kids spoke Turkish. I needed to teach them how to read and write first to teach the Turkish language. It was tough for me. The biggest problem in metropolitan cities is the lack of communication with parents.

Four teachers advocated that there would be no differences in teachers' PD needs across provinces/regions. T10 asserted that, "Maybe there is a difference in adapting to the province; otherwise, I don't see much difference."

The majority of the teachers stated that education conditions vary from region to region, and sometimes even within a city. Hence, the professional development needs of teachers also differ from region to region. In other words, the positive and negative consequences of a region's geographical, economic, and socio-cultural structure affect how teachers will direct education. Therefore, it may be beneficial for teachers to participate in professional development activities in the fields they need to determine this direction. However, some teachers thought that this difference did not affect professional development needs, only the adaptation of teachers to the region. According to their thoughts, there will be no difference when the harmony is complete.

\section{Discussion and Conclusion}

The Ministry of Education manages in-service teacher professional development at the central and local levels in Turkey. In this study, professional development training courses held by the MONE were evaluated in line with Turkish language teachers' views, and the teachers' expectations from professional development and the analysis of the current situation were presented. Following the findings of the current study and research in the literature, the following conclusions about professional development activities in Turkey have been reached.

The professional development activities organized by the MONE barely meet the educational needs of Turkish language teachers. Research on professional development for teachers has revealed different reasons for this situation. For example, Veyis (2012) argued that the reason why the activities fail to meet teachers' expectations and educational needs entirely is that the activities aim to train all teachers, that is, that they are too general. The research conducted by Yildirim (2012) put forward several other reasons, including discussing commonly known topics, lack of current topics in the program, and insufficient time for practice-oriented subjects. Our study also addressed all these problems, yet we observed a prominent reason in the findings. Teachers stated that the objectives of professional development programs were not reflected in the actual activities. Everything appeared to be suitable for the purpose on paper, but there were various problems in practice. The teachers believed that even though PD programs were not highly regarded, they were forced on teachers. Such enforcement resulted in teachers' unwillingness to participate in professional development. Some teachers even felt that they were not valued due to carelessly organized PD activities. The negative impact of politics should not be overlooked, either. There have been nine ministers in the last 20 years in Turkey, which has impeded the sustainability of professional development policies. Professional development programs could not go beyond the complementary structure and content that primarily supports the decisions of the political will 
(Günel \& Tanrıverdi, 2014). Therefore, changes in politics have had a positive or negative impact on professional development practices.

Turkish teachers $(94.7 \%)$ stated that the PD activities were ineffective for teachers to learn novel approaches; hence, the training had no effect on classroom practices. Similar results emerged in the studies conducted by Durmuş (2013), Uçar (2005), and Sezer (2006). The teachers underlined that they could not transfer their learning in professional development activities to the classroom since the training was focused on knowledge transfer and did not cover innovations in education. However, Özen's (2006) study suggested that teachers primarily benefitted from theoretical knowledge in professional development activities for teachers, which also contributed to classroom applications. It would be unfair to state that professional development activities did not contribute to teachers' professional development. As seen in the findings, some teachers found communicating with fellow teachers during the training to be as effective as the PD programs themselves (T31 and T32). Therefore, theoretical knowledge would certainly be useful. However, this result can be interpreted as an indicator of the teachers' attitudes towards professional development activities based on their negative experiences.

As knowledge transfer dominates a significant number of PD training courses, the lecturing method becomes predominant. In reference to studies with similar remarks, professional development activities are conducted in didactic form or in the form of listening presentations detached from the context (Bayrakc1, 2009; Bümen et al., 2012). Lecturing, which is generally used to attain knowledge-level objectives, is a method in which the trainer is more active than the audience. Although this method is practical, if the instructor does not enrich the learning environment with various methods and techniques, learning becomes tedious (Erciyeş, 2019). Joyce and Showers (2002), investigating the impact of teachers' professional development activities on classroom practices, stated that training carried out only in the form of presentation, lecturing, and demonstration does not facilitate classroom teaching. Our findings revealed that it was only the question-answer technique that was used to evaluate comprehension at the end of the instruction or the topic covered. We observed that trainers did not use a variety of methods and techniques. Therefore, training inevitably becomes tedious for teachers. However, the use of methods and techniques such as brainstorming and drama that incorporate high-level thinking skills during the activities can increase participants' interest in training and create an environment where they can learn from the activities and include these types of methods and techniques in their classes.

Teachers found the learning environments of the professional development activities to be appropriate for adult education. This finding contradicted the teachers' complaints about crowded halls. Both our study and other related studies (Avşar, 2006; Büyükcan, 2008; Uçar, 2005) put forward teachers' dissatisfaction with activities where hundreds of people gathered in large halls, or where the physical conditions were not suitable for adult education. However, distance turned out to be a more critical element for teachers. The teachers attached more importance to physical proximity than to an appropriate learning environment, and wished to receive training in their own school. In other words, even though the environment was not suitable for training activities, it was more important for teachers to hold PD training in their workplace. The teachers expressed their expectations regarding the learning environments as follows: There should be specially prepared environments for professional development activities that are comfortable, clean, tidy, spacious, equipped with suitable tools, not crowded, and convenient for small group work, where there are no transportation problems, and that meet physical needs and make teachers feel valuable.

When considering educational tools in the physical environment, it was observed that the teachers complained about the inadequacy and inefficient use of educational tools. Trainers do not use overhead projectors properly, and they write on transparencies and read through them. It causes a decrease in teachers' interest in PD training as well as in the efficiency of training. Teachers referred to the lack and insufficiency of educational tools (materials) as one of the 
problems in the studies by Nartgün (2006) and Büyükcan (2008). However, since these problems are not addressed in detail, the source of the problems is not identified. It was also prevalent in our findings that smartboards became a widespread educational tool upon the initiatives of the Fatih Project, and yet the teachers stated that smartboards were used as a projector.

The teachers' opinions about the duration of professional development activities revealed salient facts. Both those who considered that the duration was adequate and those who referred to the inadequate duration of training concluded that time was poorly managed in activities. Either participants' pressure or trainers' request to shorten the training time resulted in inefficacious meetings and a cursory review of in-depth topics. Thus, teachers felt bored or took the training for granted, the quality of the training decreased, and teachers failed to achieve the expected efficiency. However, the training courses appeared as if they were completed successfully. Yoon et al.'s (2007) study revealed a significant relationship between the duration of teachers' participation in teacher professional development and student learning. They indicated that an average of 49 hours of participation in substantial teacher professional development boosted students' achievement by about 21 percent. The findings also revealed that other professional development activities (often lasting 5 to 14 hours) delivered in more limited periods did not yield a statistically significant difference in the students' learning process. Therefore, reducing the time allocated to PD activities eliminates the effect of teacher professional development on student achievement. At this point, the issue of trainers' qualifications needs to be addressed. Teacher responses revealed that teachers drew more attention to trainers' communication and teaching skills than to lack of knowledge. The teachers stated that the trainers had difficulties motivating the participants and ensuring teachers' interest in the training. They also pointed out the trainers' reluctance, reporting that trainers who were forced into PD programs by their superiors projected their sense of obligation onto the participants. In a learning environment where both trainers and participants feel compelled to participate in PD, we cannot expect educational efficiency. In the studies conducted by Nartgün (2006) and Özen (2006) on the effectiveness of in-service training programs for primary school teachers, the teachers remarked that the trainers had insufficient field knowledge and did not have a good command of subject matter knowledge, that is, they were not field experts. Yildırım's (2012) study on basic training courses indicated that the formal nature of the communication between prospective teachers, trainees, and trainers negatively affected the efficiency of training. In Öz (2012) and Turgut's (2012) studies, the teachers indicated that academics should give professional development training. However, our study revealed a prominent finding concerning this proposition. Teachers remarked that some academics attempted to establish superiority in their communication with teachers and underestimated them. This situation prevents teachers from focusing on the content of the training. Some of the teachers who participated in Özen's (2006) study emphasized that some academic staff treated them as their students. Similarly, Avşar (2006) addressed teachers' inadequacies in field knowledge and mentioned the problems related to trainers' competencies in adult education. In this case, it becomes significant that field experts receive training in adult education. It is also problematized that academic staff working in teacher training institutions lack teaching experience. Teachers expressed that trainers who did not have teaching experience conveyed theoretical information and failed to provide practical examples. The findings concluded that the training sessions where trainers maintained effective communication or accommodated practical applications appeared to impact teachers, while others remained merely as a source of a participation certificate for trainees.

Teachers also drew attention to the quality of assessment and evaluation. Some PD programs carried out assessment and evaluation while others did not, yet the main problem was that measurement practices were not taken seriously. Assessment and evaluation practices where teachers copy their colleagues' answers or trainers give the answers cannot contribute to the development process. Our research echoed the results from Avşar (2006), Güneş (2006), Çiftci (2008), Durmuş (2013), Uçar (2005), and Aribaş et al. (2012), demonstrating the deficiencies 
regarding the assessment and evaluation implemented during or after professional development activities.

None of the Turkish language teachers we interviewed had postgraduate education. This result is hardly surprising. The MONE Performance Program in 2019 (2019b) reported that the ratio of teachers having completed postgraduate studies in Turkey was 8.93\%. However, Köseoğlu et al. (2020) concluded in their study that the most effective training for teachers was postgraduate education (master's and doctorate degrees). However, the teachers we interviewed in our study considered postgraduate education for professional development as a challenging goal to achieve. Teachers must take exams for postgraduate studies. Those who were willing to start a postgraduate degree referred to a lack of time to prepare for the exams. The main reason for other teachers to be reluctant was that postgraduate education would barely result in a pay raise and did not make a difference in their career planning. Teachers expected encouragement from the MONE in this regard.

Examining the teacher responses, we found that the MONE or its affiliated units did not consult with teachers to identify their professional development needs or follow up with the consultation process. The teachers who were consulted for their opinions mentioned surveys conducted with teachers. They expressed that they completed the surveys yet complained about not receiving any feedback. However, according to Angadi (2013), needs analysis should be carried out to reveal teachers' shortcomings in related subjects as the first step when determining the content of professional development programs, and the required professional support should be provided by considering the results obtained from the analysis and by integrating the conditions of the school environment where teachers work. Besides, according to the andragogical approach, adults are life-, task-, or problem-centered in their learning orientation. Adults are motivated to learn to the extent that they think that learning will help them fulfill their duties or cope with real-life situations and problems (Knowles, 2005). Teachers inevitably become reluctant to participate in activities carried out without determining their needs and desires. Besides, teachers faced feelings of insignificance when they were not provided with any feedback. As a result, we encountered teachers who gave up seeking the truth. According to the TALIS report, the lack of appropriate professional development activities was one of the main obstacles to professional development in Turkey (Büyüköztürk et al., 2010). Although teachers considered professional development to be necessary, they did not participate in activities that did not meet their needs and wishes. The teachers agreed that the programs designed by their principals or the Ministry were not effective.

Regarding timing, the majority of the teachers stated that professional development studies should be carried out during the seminar periods in early September and at the end of June. In the studies by Özan et al. (2014) and Turgut (2012), teachers articulated that it would be more beneficial to conduct professional development training at the beginning or end of the year, as happens currently, or spread the training sessions over the year. Veyis (2012) noted the teachers' remark that professional development training should be delivered in summer. Unlike the teachers' views in the abovementioned studies, our study found that teacher motivation was low in the training programs held during the year. Teachers stated that they were unable or reluctant to participate in professional development training during the academic year due to inconvenience with class hours and occupational fatigue. However, seminar periods were organized to support their professional development. During these 15-day seminar periods, the teachers had no work to do, which they thought was a significant loss of time. The teachers believed that serious approaches to professional development activities in these periods would serve their purpose. Some teachers stated that training held during the academic year would also appeal to them if their teaching hours were regarded when scheduling the events, and then they would be willing to participate in PD training.

The Turkish language teachers had the opinion that the training should mainly be compulsory. Every teacher needs development, and the institutions where teachers work should support teacher professional development. They addressed the low participation ratio in voluntary 
training, and explained that since teachers were used to working all day, they became reluctant to attend extra activities out of working hours. The findings included a prominent focus on participation status. The teachers argued that participation in professional development programs could be voluntary, but then no one would participate in voluntary training, which would impede teacher professional development. Kennedy's (2016) review of the studies comparing the effectiveness of professional development activities, where differences emerged concerning voluntary and compulsory participation, reminded us of the role of teachers' will in developing their practices. In professional development, "attendance is mandatory but learning is not." The time allocated to professional development is a significant variable. However, although presenting the amount of time and the activities performed within this time as required may increase the time allocated to professional development quantitatively, it may negatively affect achievement of the goal of professional development (Özer Özkan \& Anıl, 2014). However, we observed that many countries obligated teachers to receive professional development. For example, more than 15 European countries made it compulsory for teachers to participate in professional development activities. Similarly, teachers are obliged to participate in professional development activities for 240 hours in five years in China and 100 hours per year in Singapore (Bakioğlu, 2013). We can conclude that although voluntary participation boosts the motivation to learn, it does not ensure all teachers' development. Our participant teachers also emphasized that teachers with more inservice teaching experience were more distant towards professional development training. Some teachers may think they do not need improvement as their years of experience increase. Nevertheless, more development and change may be necessary for them. According to Göçmen (2003), the more a person believes in his/her own values, experiences, and ideas, the more s/he is closed to learning. For a person to learn, s/he needs to approach and accept different information with humility, enunciating "there is more to learn outside of the world I experience and the values I have. I don't know, but I want to learn."

Almost all Turkish teachers (94.7\%) drew attention to local planning of professional development programs. The majority supported the idea that PD planning should be managed locally because local management would be more informed about local needs. The teachers expressed that as the student and parent profiles changed, their problems changed; thus, their professional development needs were also transformed accordingly. They thought that the Ministry might overlook these needs. The findings illuminated that the teachers considered the PD planning of the Ministry as a 'top-down' application and felt enforced to participate in these PD programs. Similarly, Öz (2012) argued that professional development programs should move away from center-based applications and focus on activities aiming to solve local problems. Since professional development activities are perceived as an essential tool in promoting and disseminating national education policies in our country, the conceptual scheme of these training courses is generally determined by the Ministry's central units. However, centrally managed activities often fail to take into account teachers' current needs and expectations and therefore, cannot always be efficient. Teachers had the opinion that the Ministry should determine local needs by conferring with the local management even though the planning was firmly central.

Another notable finding in the study was that professional development was perceived merely as courses and seminars. The teachers we interviewed listed the names of the seminars and courses when asked about the professional development activities in which they had participated. We examined a sample in-service training program prepared by the MONE Professional Development Support and Monitoring Department following the updated quality criteria (MONE, 2021), and found that it merely included courses, seminars, and pre-service preparation programs. The traditional understanding, which regards professional development training as a process in which teachers gain knowledge and skills with one-time courses or seminars, has been criticized for the following reasons: the school context is not factored into the training, the training is not grounded in classroom practice, and it is out of alignment with current theories of teaching and learning (Borko et al., 2010). The fact that professional development programs fail to consider teachers' 
autonomous learning skills and interaction among colleagues and teachers, and hence position teachers as passive actors in the process, should be seen as a hindrance to the success of professional development. Haydn et al. (2008) revealed that letting teachers have a say in determining their own learning agendas for their PD and exchanging ideas with each other is a great driving force in terms of professional development.

\subsection{Recommendations}

Considering the results of the study, the following recommendations are made:

1. Teacher development positively impacts student achievement. Therefore, teachers' PD needs should be identified, and PD programs should be planned and implemented accordingly.

2. Professional development should be perceived as more than just courses and seminars. Teachers should be provided with various options for professional development rather than having one type of PD program enforced on them.

3. Fundamental to education, parents, students and environmental factors vary across provinces/regions. Hence, teachers' problems and PD needs also vary across provinces/regions. Local differences and needs should be taken into account in PD planning, and the planning should be locally oriented. The MONE should conduct local research to determine teachers' needs, and PD programs should be prepared based on teachers' demands, expectations, and needs. This would enable teachers to feel regarded in their institution.

4. Teachers should be obliged to participate in professional development activities for a certain period of time (e.g., 49 hours). Such an obligation serves as a qualitative measurement among teachers. However, teachers should be given the option to select the activities to attend, and the topics, the places and the schedules, which would enable them to participate in PD voluntarily.

5. It should be noted that PD needs vary among teachers in different fields. Therefore, activities/training should be designed by regarding these differences across fields. Teachers of the same field can gather to motivate each other, which contributes to teacher development.

6. The trainers should be experts in their fields, have advanced teaching skills, be knowledgeable about adult education, and also have teaching experience. The MONE should continuously train the trainers regarding educational methods and techniques, adult education, and psychology of teaching and learning. Furthermore, the MONE should collaborate with the faculties of education in the universities.

7. Teachers should be provided with an opportunity to participate in PD activities via distance education. It should be ensured that distance education programs are well-designed and allow teachers to progress gradually. Also, these programs need to be subjected to serious evaluation. Teachers should be able to participate in training on a subject they need or want to learn, and to progress in the training as they learn successfully.

8. Teachers who are engaged in PD should be rewarded (promotion, seniority, etc.) to encourage participation in PD. The promotion of postgraduate/doctorate students in state universities should be facilitated.

9. Teachers' professional development should not be perceived as the responsibility of the MONE alone. Teachers should be seen as individuals who shape societies, and state and private institutions/organizations should take part in their development. Universities, non-governmental organizations, private companies, and municipalities should carry out short or long-term activities, accommodating teachers' interests, needs and wishes, and develop joint projects with the MONE. Universities should support teachers' development by delivering open courses or accepting teachers as special students for postgraduate courses. Moreover, some of the voluntary PD activities prepared by these institutions/organizations may also be paid, thus providing financial benefits to the organizers. In that case, teachers should be able to request financial support from the MONE, and the Ministry should support teachers as much as it is feasible. 
Acknowledgements. This research is produced from the doctoral dissertation supervised by Prof. Dr. Sedat Sever titled "A professional development program design for the Turkish language teachers."

\section{References}

Angadi, G. R. (2013). Best practices in teacher professional development. International Journal of Education $\mathcal{E}$ Psychological Research, 2(2), 8-12.

Arıbaş, S., Kartal, Ş. \& Çağlar, İ. (2012). The opinions of English teachers about in-service training activities. Journal of National Education, 195, 241-254.

Arık, K. (2017). Primary and secondary school teachers' perception on in-service education after 4+4+4 system (Kutahya sample) [Unpublished master's thesis]. Çanakkale Onsekiz Mart University, Çanakkale, Turkey.

Aslan Keleș, H. (2019). Evaluation of in-service training organized by the manager of education administrators and teachers [Unpublished master's thesis]. Kırıkkale University, Kırıkkale, Turkey.

Avc1, E. (2018). Determining the in-service training needs of teachers [Unpublished master's thesis]. Yeditepe University, Istanbul, Turkey.

Avşar, P. (2006). Physical education teachers' evaluation of in-service training programme employed [for] them [Unpublished master's thesis]. Ankara University, Ankara, Turkey.

Bakioğlu, A. (Ed.). (2013). Karşılaştırmalı eğitim yönetimi, PISA'da başarnlı ülkelerin eğitim yönetimi [Comparative education management, education management of successful countries in PISA]. Nobel.

Balkı, M. (2013). The evaluation in-service training applications of the Ministry of National Education: Kastamonu province candidate teachers model [Unpublished master's thesis]. Gazi University, Ankara, Turkey.

Baştürk, R. (2012). Investigation of elementary school teachers' perceptions and expectations about in-service education. Hacettepe University Journal of Education, 42, 96-107.

Bayrakc1, M. (2009). In-service teacher training in Japan and Turkey: A comparative analysis of institutions and practices. Australian Journal of Teacher Education, 34(1), 10-22.

Bilgin, N. (2014). Sosyal bilimlerde içerik analizi, teknikler ve örnek çalışmalar [Content analysis, techniques and sample studies in social sciences]. Siyasal.

Borko, H. \& Putnam, R. T. (1995). Expanding a teacher's knowledge base: a cognitive psychological perspective on professional development. In T. R. Guskey M. Huberman (Eds.), Professional Development in Education: New Paradigms and Practices (pp. 35-66). Teachers College Press.

Borko, H., Jacobs, J., \& Koellner, K. (2010). Contemporary approaches to teacher professional development. International Encyclopedia of Education, 7, 548- 556. https:// doi.org/10.1016/B978-0-08-044894-7.00654-0

Özan, M. \& Polat, G. (2014). Determination of the general views of class teachers regarding their career development training. Uşak University Journal of Social Sciences, 7(4), 167-180.

Bümen, N., Ateş, A., Çakar, E., Ural, G. \& Acar, V. (2012). Teachers' professional development in Turkish context: Issues and suggestions. Journal of National Education, 194, 31-50.

Büyükcan, Y. (2008). Effectiveness of in-service training seminars for teachers in primary schools [Unpublished master's thesis]. Hacettepe University, Ankara, Turkey.

Büyüköztürk, Ş., Kılıç Çakmak, E., Akgün, Ö. E., Karadeniz, Ş., \& Demirel, F. (2012). Bilimsel araştırma yöntemleri [Scientific research methods]. Pegem.

Büyüköztürk, Ş., Akbaba Altun, S. \& Yıldırım, K. (2010). TALIS Türkiye ulusal raporu [TALIS Turkey national report]. MONE General Directorate of Foreign Relations.

Craft, A. (2000). Continuing professional development. Routledge.

Creswell, J. (2015). Qualitative inquiry and research design: Choosing among five approaches. SAGE.

Çiftci, E. (2008). An analysis of education given to in-service music teachers by Ministry of National Education in Turkey and determining the needs for in-service training of music teachers [Unpublished doctoral dissertation]. Gazi University, Ankara, Turkey.

Darling-Hammond, L. (2000). Teacher quality and student achievement: a review of state policy evidence. Educational Policy Analysis Archives, 8(1), 1-44. https://doi.org/10.14507/ epaa.v8n1.2000

Desimone, L. M., Smith, T. M., Hayes, S., \& Frisvold, D. (2005). Beyond accountability and average math scores: Relating multiple state education policy attributes to changes in student achievement in procedural knowledge, conceptual understanding and problem solving in mathematics. Educational Measurement: Issues and Practice, 24(4), 5-18. https:// doi.org/10.1111/j.1745-3992.2005.00019.x

Drage, K. (2010). Professional development: Implications for Illinois career and technical education teachers. Journal of Career and Technical Education, 25(2), 24-37. 
Durmuş, E. (2013). Investigation of teachers 'professional development' opinions [Unpublished master's thesis]. Celal Bayar University, Manisa, Turkey.

Eğitim-Bir-Sen (2016). Eğitime bakış 2016. İzleme ve değerlendirme raporu [Education overview, 2016. Tracing and evaluation report]. http://www.ebs.org.tr/ebs_files/files/yayinlarimiz/egitim_izleme_raporu.pdf

Erciyeş, G. (2019). Öğretim yöntem ve teknikleri [Teaching methods and techniques]. In Şeref Tan (Ed.), Ögretim ilke ve yöntemleri [Teaching principles and methods](pp. 143-218). Pegem.

Feiman-Nemser, S. (2001). From preparation to practice: designing a continuum to strengthen and sustain teaching. Teachers College Record, 103(6), 1013-1055.

Fraenkel, J. R., \& Wallen, N. E. (2009). How to design and evaluate research in education. The McGraw-Hill Companies.

Ganser, T. (2000). An ambitious vision of professional development for teachers. NASSP Bulletin, 84(618), 612. https://doi.org/10.1177/019263650008461802

Göçmen, A. (2003). Yeniden öğrenme: yetişkinler için el kitabı [Re-learning: a handbook for adults]. Nobel.

Guskey, T.R. (2000). Evaluating Professional Development. Corwin Press.

Günel, M., \& Tanrıverdi, K. (2014). In-service teacher training from international and national perspectives: The retention and loss of institutional and academic memories. Education and Science, 39(175), 73-94. https://doi.org/10.15390/EB.2014.2949

Güneş, M. (2006). The reasons for the primary school teacher's being willing or unwilling to participate in inservice training programmes [Unpublished master's thesis]. Hacettepe University, Ankara, Turkey.

Haydn, T., Barton, R. \& Oliver, A. (2008). An alternative model of continuing professional development for teachers: Giving teachers time. International Education Studies, 1(1), 44-49.

Joyce, B. \& Showers, B. (2002). Student achievement through staff development. Association for Supervision and Curriculum Development.

Karasar, N. (2014). Bilimsel araştırma yöntemi [Scientific research method]. Nobel.

Karasolak, K., Tanriseven, I. \& Konokman, G. Y. (2013). Determining teachers' attitudes towards inservice education activities. Kastamonu Education Journal, 21(3), 997-1010.

Karip, E. (Ed.) (2019). TALIS 2018 sonuçları ve Türkiye üzerine değerlendirmeler [TALIS 2018 results and reviews on Turkey]. Turkish Education Association.

Kaya, S., Şahin, H., Fırat, A., Maden, Ö., Eruçar, İ. O. \& Ceren, A. (2013). Investigating the satisfaction levels of teachers teaching subject matters out of their area of certification during 2012-2013 educational year in terms of different variables. International Journal of Turkish Literature Culture Education, (2/2),302-335. https://doi.org/10.7884/teke.179

Kennedy, M. M. (2016). How does professional development improve teaching? Review of Educational Research, 86(4), 945-980. https:/ / doi.org/10.3102/0034654315626800

Knowles, M. (2009). Androgoji: Yetişkinlerde öğrenme konusunda yeni bir teknoloji [Androgogy: A new technology for adult learning] (Serap Ayhan, Trans.), In A. Yıldız \& M. Uysal (Ed.), Yetişkin eğitimi [Adult education]. Kalkedon.

Köseoğlu, F., Tahancalıo, S., Kanlı, U. \& Özdem Yılmaz, Y. (2020). Investigation of science teachers' professional development needs for learning in science centers. Education and Science, 45(203) 191-213.

Lune, H., \& Berg, B. L. (2017). Qualitative research methods for the social sciences. Pearson.

McKinsey Report. (2007). How the world's best-performing school systems come out on top. http://alamin99.wordpress.com/2008/02/22/mckinsey-report/

Merriam, S. B., \& Tisdell, E. J. (2015). Qualitative research: A guide to design and implementation. John Wiley \& Sons.

Miles, M, B., \& Huberman, A. M. (1994). Qualitative data analysis: An expanded sourcebook. (2nd Ed.). Sage.

Ministry of National Education. [MoNE]. (2006). Millî̀ Eğitim Bakanlı̆̆ı hizmetiçi eğitim faaliyetlerinin değerlendirilmesi [Evaluation of in-service training activities of the Ministry of National Education]. MoNE.

Ministry of National Education. [MoNE]. (2008). Öğretmen Yeterlikleri, Öğretmenlik Mesleği Genel ve Özel Alan Yeterlikleri Teacher [Competencies, Teaching Profession General and Special Field Competencies]. Goverment Books.

Ministry of National Education. [MoNE]. (2010). Milli Eğitim Bakanlığında hizmetiçi eğitimin yeniden yapılandırnlması panel ve çalıştayı [Panel and workshop on restructuring in-service training in the Ministry of National Education]. MoNE.

Ministry of National Education. [MoNE]. (2015a). Milli eğitim kalite çerçevesi [National education quality framework]. Resmi Gazete [Official Newspaper], No: 29364. 
Ministry of National Education. [MoNE]. (2015b). MEB 2015-2019 stratejik planı [2015-2019 strategic plan for MONE]. MoNE.

Ministry of National Education. [MoNE]. (2018). Türkçe dersi öğretim programı (1-8. Sınıflar) [The curriculum for the subject of Turkish (for 1st-8th grades)]. MoNE.

Ministry of National Education. [MoNE]. (2019a). MEB 2019-2023 Stratejik Planı [2019-2023 Strategic Plan for MoNE]. MoNE.

Ministry of National Education. [MoNE]. (2019b). 2019 yll performans programı [Performance plan for 2019]. MoNE http://sgb.meb.gov.tr/meb_iys_dosyalar/2019_11/25140550_2019_PP_yayYn.pdf

Ministry of National Education [MoNE]. (2021). Geliştirilen ve Güncellenen Standart Kriterlere Uygun olarak hazırlanan Örnek Hizmetiçi Eğitim Programlar [Sample In-Service Training Programs prepared in accordance with the Developed and Updated Standard Criteria]. MoNE. http://oygm.meb.gov.tr/dosyalar/StPrg/

Mustan, T. (2002). Dünyada ve Türkiye'de öğretmen yetiştirmede yeni yaklaşımlar [New approaches in teacher education in the world and Turkey]. Educational Administration: Theory and Practice, 29, 115-127.

Nartgün, S. S. (2006). Perceptions of primary school teachers in relation to the effects of inservice training (INSET) programs (A case study: Bolu). University of Abant İzet Baysal Journal of Faculty of Education, 6(1), 157-178.

Öz, A. (2012). The contribution of inservice education organized within the Ministry of National Education to professional development of religious culture and ethics course teachers (The case of Istanbul) [Unpublished doctoral dissertation]. Marmara University, Istanbul, Turkey.

Öz, M. F. (2011). Uygulamalı Türkçe öğretimi [Applied Turkish teaching]. Anı.

Özcan, M. (2011). Bilgi çağında öğretmen eğitimi, nitelikleri ve gücü, bir reform önerisi [Teacher education, qualifications and power in the information age, a reform proposal]. Turkish Education Association.

Özen, R. (2006). Perceptions of primary school teachers in relation to the effects of inservice training (INSET) programs (A case study: Düzce). University of Abant İzet Baysal Journal of Education Faculty, 6(2), 141-160.

Özer Özkan, Y. \& Anıl, D. (2014). Discriminations of variable of teachers professional development. Hacettepe University Journal of Education, 29(4), 205-216.

Paker, T. (2008). Problems of student teachers regarding the feedback of university supervisors and mentors during teaching practice. Pamukkale University Journal of Education, 23, 132-139.

Patton, M. Q. (2014). Qualitative research \& evaluation methods. Sage.

Republic of Turkey Ministry of Development (2013). Tenth development plan (2014-2018). http://www.Kalkinma.Gov.Tr/Lists/Kalknma\%20planlar/Attachments/12/Onuncu\%20kalk\%C4\%B1n ma\%20plan\%C4\%B1.Pdf

Richter, D., Kunter, M., Klusmann, U., Lüdtke, O. \& Baumert, J. (2014). Professional development across the teaching career: Teachers' uptake of formal and informal learning opportunities. In S. Krolak-Schwerdt, S. Glock \& M. Böhmer (Eds.), Teachers' professional development, assessment, training, and learning (pp. 97-121). Sense Publishers.

Sever, S. (2001). Öğretim dili olarak Türkçenin sorunları ve öğretme-öğrenme sürecindeki etkili yaklaşımlar [Problems of Turkish as a language of instruction and effective approaches in the teaching-learning process]. Ankara University Journal of Faculty of Educational Sciences (JFES), 34(1), 11-22. https://doi.org/10.1501/Egifak_0000000047

Sezer, E. (2006). Ministry of Education, state schools' guidance counselors' and psychological consultants' views regarding in-service training [Unpublished master's thesis]. Yeditepe University, Istanbul, Turkey.

Sparks, D. \& Loucks-Horsly, S. (2007). Five models of staff development for teachers. In A. C. Ornstetin, E. J. Pajak \& S. B. Ornstein (Eds.), Contemporary Issues in Curriculum (p. 303-326). Pearson.

Strategy and Budget Department of the President of the Republic of Turkey (2019). Eleventh development plan. http://www.sbb.gov.tr/wp-content/uploads/2019/07/OnbirinciKalkinma Plani.pdf

Tavşancıl, E. \& Aslan, A. E. (2001). Sözel, yazılı ve diğer materyaller için içerik analizi ve uygulama örnekleri [Content analysis and practice examples for verbal, written, and other materials]. Epsilon.

Taş, U. E., Arıcı, Ö., Ozarkan, H. B. \& Özgürlük B., (2016). PISA 2015 ulusal raporu [PISA 2015 national report]. MONE.

Turgut, S. (2012). Determination of primary school teachers' in-service training needs [Unpublished master's thesis]. Mehmet Akif Ersoy University, Burdur, Turkey.

Türkhan, H. (2008). The evaluation of the distance in-service training given in the computer training practices of the Ministry of Education [Unpublished master's thesis]. Yeditepe University, Istanbul, Turkey. 
Uçar, R. (2005). The opinion of the administrators and the teachers working in elementary schools related to the inservice training practices of the Ministry of National Education [Unpublished master's thesis]. Yüzüncü Yıl University, Van, Turkey.

Ulus, O. (2009). According to teachers' views, the assessment of inservice educational programmes [Unpublished master's thesis]. Gazi University, Ankara, Turkey.

Ülker, A. (2009). Thoughts of classroom teachers about in-service training (Sample of Konya/Karapinar district) [Unpublished master's thesis]. Selçuk University, Konya, Turkey.

Veyis, F. (2012). Determination of Turkish language and literature teachers' requirements of the in-service education and training [Unpublished master's thesis]. Atatürk University, Erzurum, Turkey.

Villegas-Reimers, E. (2003). Teacher professional development: an international review of the literature. International Institute for Educational Planning.

Yildırım, M. C. (2012). A study on contribution of the basic training course to the professional development of probationary teachers. Educational Sciences: Theory and Practice, 12(3), 1867-1886.

Yıldırım, A. \& Şimşek, H. (2011). Sosyal bilimlerde nitel araştırma yöntemleri [Qualitative research methods in the social sciences]. Seçkin.

Yıldız, H. \& Arıbaş, S. (2012). The evaluation of intel inservice teacher training program. Journal of National Education, 193, 55-69.

Yoon, K. S., Duncan, T., Lee, S. W. Y., Scarloss, B., \& Shapley, K. (2007). Reviewing the evidence on how teacher professional development affects student achievement (Issues and answers report). Regional Educational Laboratory Southwest.

Yurtseven Yılmaz, H. \& Gülçiçek Esen, D. (2015). An investigation on in-service trainings of the Ministry of National Education (MONE). Procedia-Social and Behavioral Sciences, 186, 79-86. https://doi.org/10.1016/j.sbspro.2015.04.019 